\title{
A legislative failure of epidemic proportions
}

Published at www.cmaj.ca on June 12, 2008.

$\mathrm{T}$ hrice in a decade - in 1999, 2002 and now in 2008 - the Auditor General of Canada has slammed Ottawa and the provinces for doing an indolent job of protecting Canadians from epidemic emergencies. And thrice in a decade, she has been ignored.

Today, there is not a politician in the country who has not heard of SARS or avian influenza, and who is not aware that a massive epidemic or pandemic could kill tens or hundreds of thousands of Canadians within weeks or months. Yet the federal and provincial governments cannot agree on how they will share epidemiologic information in a disease outbreak.

While "epidemiologic information" sounds mundane, it is at the core of understanding the scope, focus and severity of an epidemic and what it will take to control it. Sometimes an epidemic's growth is exponential: 1 diseased person may infect 2, who infect 4, and so on. Each doubling (or worse) can take only days. There is no time in an emergency to haggle over access to epidemiologic information. Time lost is tantamount to lives lost.

These scientific realities are clear enough, but for the last decade Ottawa and the provinces have ignored them. Instead of building a system to rapidly share epidemiologic information - the better to coordinate a national and international response during crises - Canada's governments don't share. Consider what the Auditor General wrote in May 2008:

To obtain routine surveillance information, the [Public Health Agency of Canada] relies on the goodwill of the provinces and territories. However, due to gaps in its information-sharing agreements with them, it is not assured of receiving timely, accurate and complete information. A data-sharing agreement recently signed with Ontario re-established the regular flow of information about individual cases after two years when this flow was limited. However, the Agency has not reached similar data-sharing agreements with the remaining provinces and territories.

Fully 12 of 13 provinces and territories are under no obligation to share information with the federal government or the rest of Canada during an outbreak. Only Ontario, humbled by the SARS epidemic, does so. When the World Health Organization (WHO) placed a travel advisory on Toronto, it was not because that city had an unparalleled number of SARS cases (Singapore had about the same), but because Ontario was coy about informing Ottawa of the epidemic's nosocomial and community reach. ${ }^{2}$

These concerns have been noted before. A decade ago, the Auditor General criticized our "lack of common standards and agreed-upon procedures for reporting [epidemic] information at the provincial and territorial levels." ${ }_{3}$ Health Canada agreed and promised to "commence discussion of this important issue." " Discussion failed. At the rate of 1 province (Ontario) agreeing to share information in a decade, it will take until the next century to cover all of Canada.

To be fair, Parliament has taken some bold steps. If a chicken carrying avian influenza were found tomorrow, Ot- tawa would be ready. There are federal laws to inspect farms for disease, to quarantine them if need be and to punish anyone concealing the epidemic. ${ }^{4}$ But if a human carrying avian influenza were found, too bad.

We at $C M A J$ believe this is a national embarrassment. As explained by Wilson and colleagues ${ }^{5}$ in this issue, Canada has new, pressing obligations to the world to manage epidemics within its borders. Since discussion and negotiation with the provinces and territories has faltered, Ottawa must now legislate to compel them to share epidemiologic information in times of emergency.

Under Canada's constitution, Parliament has jurisdiction to legislate for emergencies, such as epidemics. ${ }^{6}$ It also may criminalize harmful conduct, such as concealing epidemiologic information. Federal laws already require disclosure of many types of public health information, such as the labelling of medicines. Surely Parliament can legislate to make epidemic information available too. Other countries, like the United States and Australia, have already done so.

Parliament's deference to the provinces on this issue has reached a ridiculous, potentially tragic, level. In a deadly epidemic, Ottawa's laws to protect Canadian poultry are stronger than its laws to protect Canadian people. Parliament must urgently legislate a way past the jurisdictional schisms before the Auditor General reminds us - again — that it is dangerously overdue. Or worse, before a deadly epidemic demonstrates our failures.

\section{Amir Attaran LLB DPhil}

Canada Research Chair in Law, Population Health and

Global Development Policy

University of Ottawa

Ottawa, Ont.

With the Editorial-Writing Team

(Paul C. Hébert MD MHSc, Rajendra Kale MD,

Matthew B. Stanbrook MD PhD, Barbara Sibbald BJ, Ken Flegel MDCM MSc and Noni MacDonald MD MSc)

Competing interests: See www.cmaj.ca/misc/edboard.shtml.

\section{REFERENCES}

1. 2008 May report of the Auditor General of Canada. Ottawa: Office of the Auditor General of Canada. Available: www.oag-bvg.gc.ca/internet/English/aud_ch_oag 20080505 e $30701 . h t m l$ \#hd5o (accessed 2008 May 27).

2. National Advisory Committee on SARS and Public Health. Learning from SARS - renewal of public health in Canada. Ottawa: Health Canada; October 2003.

3. 1999 September report of the Auditor General of Canada. Ottawa: Office of the Auditor General of Canada. Available: www.oag-bvg.gc.ca/internet/English/aud_ch _oag_199909_14_e_10143.html\#0.2.2Z141Z1.WEAMVH.CZQ0IF.R5 (accessed 2008 May 27).

4. Health of Animals Act, SC 1990, c 21.

5. Wilson K, von Tigerstrom B, McDougall C. Protecting global health security through the International Health Regulations: requirements and challenges. CMAJ 2008; 179:44-8.

6. Attaran A, Wilson K. A legal and epidemiological justification for federal authority in public health emergencies. McGill Law J 2007;52:382-414. 